that whereas before the war the formation of majorities was a comparatively simple task this became increasingly difficult after the war and utterly impossible when in 1932 the political scene was dominated b ythe famous "five totalitarian systems." These are just a few of the shortcomings of the book, which differs from the one by Mr. Hallett in that it contains in no way a refinement of the theory of $\mathrm{P}$. R.

Whereas there would be little reason to expect the good from P. $\vec{R}$. which its friends attribute to it, this is different with regard to another institutional change, namely the adoption of unicameral legislatures in the several states constituting this country. The two little volumes edited by Dr. Aly clearly bear this out. They contain articles in magazines and newspapers on the subject as well as excerpts from books concerning it. The selection is made with great care, and the reader cannot fail to become acquainted with all the aspects of the matter. For it must be added that all possible objections are analyzed, so that no attempt is made to convey the impression to the reader that if only the proposed institutional change is adojted, all imperfections will disappear from the political life of this country. Of course, for the thoughtful reader an argument presented this way only gains in strength. The movement in favor of unicameral legislatures will benefit from this book, and so will every student of American politics who uses it. It contains material of importance which otherwise would not be easily available.F. A. Hermens, University of Notre Dame.

\title{
REV. VIRGIL MICHEL, O.S.B. $\nmid$
}

Virgil Michel, who died November 26 at St. John's Abbey, Collegeville, Minn., was one of those Americans most effectively engaged in trying to understand our civilization and our urgent social problems. He saw that our politics has become absorbed in an economic system which, by way of the machine, has depersonalized the life of man; yet he said that the attempt to replace "the individualistic or atomistic conception of society by the proper notion of human society as a moral union of individuals cooperating or striving together toward a common good," and as an organic fellowship, must "also deal with the financial structure or set-up of modern life." His aim was to re-personalize our life, and he thought the person the center and aim of all genuine reconstruction. He stood against social atomism and for solidarity, and said that most of us are aware of the dangers in communism and fascism but not of the "more insidious menace that modern capitalism or bourgeois civilization is to all spiritual values." Among his works are a series of booklets on The Social Question (The Wanderer Press, St. Paul) and Christian Social Reconstruction (Bruce, Milwaukee). This Review is happy to announce for the next number one of his best productions, an article on "Ownership and the Human Person." 